\title{
Complication of foldable single- piece intraocular lens sulcus implantation in a child under two years old
}

Julie Dewi Barliana

Department of Ophthalmology, University of Indonesia, Jakarta, Indonesia

\section{Abstract}

A two-and-a-half-year-old boy presented to Cipto Mangunkusumo Hospital, Jakarta, Indonesia with a white spot on his left eye. He had cataract surgery one year prior at another hospital. On examination, corectopia, anterior synechiae, white plaque between the iris and corneal endothelium, a shallow anterior chamber, and an intraocular lens $(\mathrm{IOL})$ in the posterior chamber were found. As a result, anterior chamber reformation and IOL explantation was performed.

Intraoperatively, a foldable single-piece IOL was found in the ciliary sulcus. Hence, extreme inflammatory process after the operation was unavoidable. One month after the procedure, the cornea was opaque without an increase in intraocular pressure. It is recommended to perform IOL implantation only in children over two years of age with a corneal diameter more than $9 \mathrm{~mm}$. A three-piece IOL might be implanted in the area of the ciliary sulcus only if the child needs an immediate IOL implant.

Keywords: congenital cataract, intraocular lens (IOL), single-piece IOL, three-piece IOL

Correspondence: Julie Dewi Barliana, MD, Jln. Percetakan Negara 7 Nomor 6, Jakarta, Indonesia.

E-mail: juliedbarliana@gmail.com 


\section{Komplikasi implantasi kanta intraokular tunggal yang boleh dilipat pada kanak-kanak di bawah umur dua tahun}

\section{Abstrak}

Seorang budak lelaki berusia dua dan setengah tahun diserahkan kepada Hospital Cipto Mangunkusumo dengan mata putih di mata kirinya. Dia menjalani pembedahan katarak satu tahun sebelumnya di hospital lain. Pemeriksaan mendapati terdapat corectopia, synechia anterior, plak putih antara iris dan endothelium kornea, ruang anterior cetek, dan kanta intraokular (IOL) di ruang posterior. Seterusnya, ruang anterior dibentuk semula dan IOL di eksplant.

Semasa intraoperatif, IOL tunggal ditemui dalam sulcus ciliary. Disebabkan itu, proses keradangan yang banyak selepas pembedahan tidak dapat dielakkan. Sebulan selepas prosedur, kornea menjadi putih tanpa peningkatan tekanan intraokular. Adalah disyorkan untuk melaksanakan implantasi IOL hanya pada kanak-kanak berusia lebih dua tahun dengan diameter kornea lebih dari $9 \mathrm{~mm}$. IOL jenis tiga-keping mungkin di implan di kawasan sulcus ciliary hanya jika kanak-kanak tersebut memerlukan implan IOL segera.

Kata kunci: IOL tiga-keping, IOL tunggal, kanta intraokular (IOL), katarak kongenital

\section{Introduction}

Congenital cataract is considered one of the most common causes of preventable childhood blindness; cataract surgery is the gold-standard treatment. However, treatment results may vary, given that many factors determine the result. This case report highlights a possible complication of single-piece intraocular lens (IOL) sulcus implantation in a one-and-a-half-year-old infant that resulted in blindness.

\section{Case report}

A two-year-old boy was brought to Cipto Mangunkusumo Hospital by his mother, who noticed a whitish lesion in his left eye. The lesion first appeared six months ago and enlarged ever since. No redness, pain, or discharge was reported. The patient was born with congenital rubella syndrome and had a history of bilateral congenital cataracts. Both cataracts had undergone surgeries at another hospital. His right eye 
underwent cataract surgery when the patient was six months old, whereas his left eye underwent cataract surgery and IOL implantation when he was one-and-a-half years old. He was also prescribed with $\mathrm{S}+10.00$ aphakia glasses for the right eye, for which the patient was not compliant.

Initial examination revealed that both eyes had nystagmus, good pupillary light reflex, and positive object fixation. Both corneas were $9 \mathrm{~mm}$ in diameter. For the right eye, the cornea was clear and no IOL was present. However, we saw multiple inhomogeneous white lesions on the left corneal endothelium, located at the 12 to 1 o'clock and at the 7 to 10 o'clock positions, all of which were associated with iris-endothelial adhesions resulting in a very shallow anterior chamber. Correctopia and peripheral iridectomy were present at the 12 o'clock postion. The IOL itself was present in the retropupillary area (Fig. 1). Fundoscopy examination of both eyes was normal with healthy discs and macula.

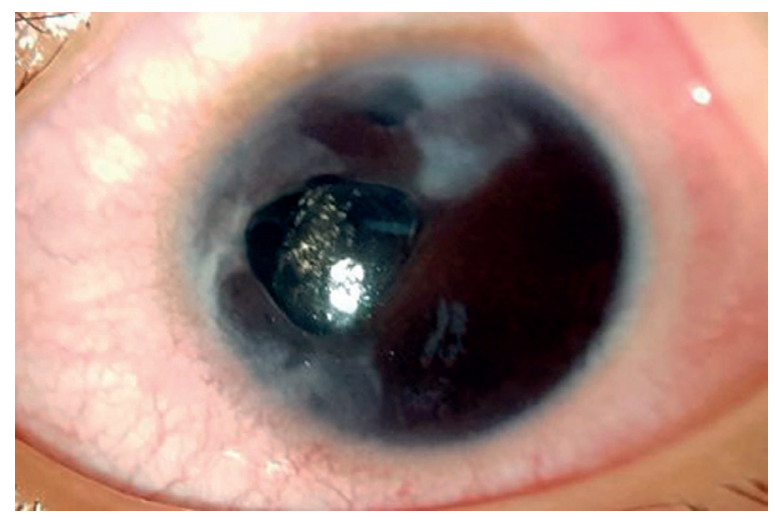

Fig. 1. IOL in the retropupillary area.

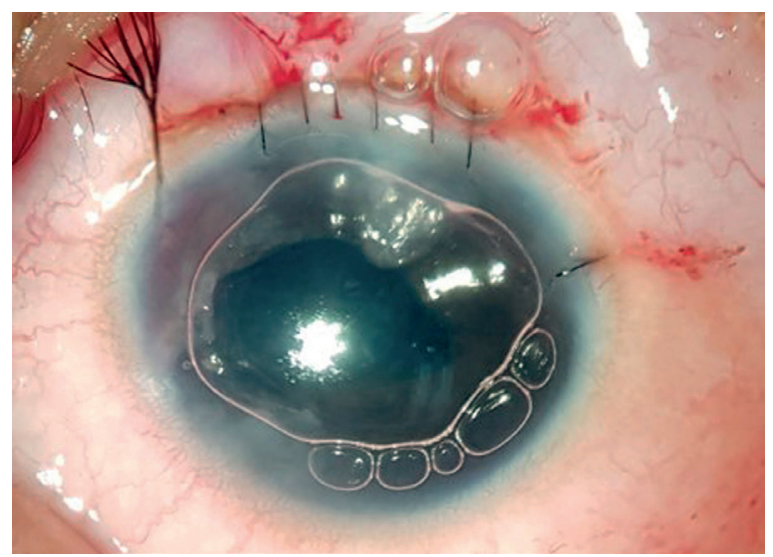

Fig. 2. Deep anterior chamber and no further iris adhesions on day 1 after surgery. 
After our thorough examination, we decided to deepen the anterior chamber and to halt the progression of the opacified cornea by explanting the IOL. In addition, IOL explantation would optimize his visual function, as he had no complaint in wearing eyeglasses.

The left eye underwent explantation of IOL, synechiae release, and anterior chamber reformation procedure. The surgery was challenging, as the adhesions made it difficult to explant the IOL. Despite the odds, the synechiae release was successful. Explantation of the IOL showed that the IOL was a single-piece foldable acrylic that was placed in the ciliary sulcus.

On day 1 after surgery (Fig. 2), the anterior chamber was deep with 3+ cells and flare 1+. There were no further iris adhesions. Intraocular pressure was also within normal limits.

On one-week follow-up, the patient came with a relatively deep anterior chamber, but there was shallowing at the 7 to 1 o'clock position peripherally. The whitish lesions extended even larger than preoperatively.

One month after surgery, examination revealed that his left cornea was already fully cloudy with only vaguely visible central pupil. After one-month examination, the patient was lost to follow-up.

\section{Discussion}

There have been inconclusive debates for determining the best time for IOL implantation in patients from six months to two years of age who have undergone cataract surgery due to congenital cataract. ${ }^{1,2}$ A study by Shamrani and Turkmani found successful IOL implantation in 120 pediatric patients under the age of two, finding the procedure beneficial to the patients' visual rehabilitation. However, close attention to another relative contraindication, such as corneal diameter $<9 \mathrm{~mm}$ or anterior segment dysgenesis, should be taken before implanting an IOL in pediatric patients in this age range. ${ }^{1}$

Aside from the timing of IOL implantation, IOL type and implantation technique also play an important role. With a $6 \mathrm{~mm}$ optic diameter, total length of $12.5-13$ $\mathrm{mm}$, and no haptic angulation, a foldable, hydrophobic single-piece acrylic IOL has been the ideal option for pediatric patients. ${ }^{3}$ This IOL type is very adaptable and can easily be implanted in the small capsular bag of pediatric patients. ${ }^{1,4}$

In-the-bag IOL implantation should always be the choice for IOL implantation, but it is not possible to implant the IOL in the capsular bag in the presence of posterior capsular rupture, zonule rupture, or in a secondary IOL implantation. ${ }^{3}$ In these instances, implantation can be performed in the ciliary sulcus. ${ }^{2}$ It is advised to use a hydrophobic three-piece acrylic IOL for in-the-sulcus implantation, as it has slimmer haptic and larger overall diameter $(13-13.5 \mathrm{~mm})$. This IOL will have less iris-to-IOL contact and presents more stable IOL centration. Furthermore, its 
posterior haptic angulation (around $5-10^{\circ}$ ) also contributes to reduced contact with surrounding tissue, as well as reduced friction between the iris and IOL. ${ }^{5,6}$

IOL implantation, and especially single-piece IOLs, in the sulcus area in pediatric patients is still debatable given that single-piece IOL sulcus implantation can chafe the posterior iris stroma, leading to a severe inflammatory reaction..$^{5,6}$ In addition, it increases the likelihood of IOL malposition and produces shallower anterior chamber. ${ }^{3}$ In this case, there was a severe inflammatory reaction due to single-piece IOL sulcus implantation which chafed the posterior iris and resulted in the formation of iris-endothelial adhesions. Indisputable severe inflammatory reaction occurred at day 1 postoperative due to excessive intraocular manipulation to explant the $\mathrm{IOL}$ and release the adhesion. On one-month examination, the whole cornea had opacified.

In cases where implantation of a single-piece IOL in the sulcus is inevitable, long-term monitoring for signs of chronic inflammation and glaucoma is required, ${ }^{7}$ as early management of inflammation may result in a better visual outcome.

\section{Conclusion}

IOL implantation as a treatment for pediatric cataract patients not only needs to consider the patient's age and corneal diameter at the time of implantation, but also the type of IOL type and implantation technique. As demonstrated in this case, implantation of a single-piece IOL in the sulcus area results in chronic inflammation involving the anterior structure; explantation cannot cease nor reverse the severe inflammation, which resulted in blindness for this particular patient.

\section{References}

1. Shamrani MA, Turkmani SA. Update of intraocular lens implantation in children. Saudi J Ophthalmol. 2012;26(3):271-275.

2. American Academy of Ophthalmology. 2014-2015 Basic and Clinical Science Course (BCSC): Section 6: Pediatric Ophthalmology and Stabismus. Lueder. GT, editor. San Francisco; American Academy of Ophthalmology: 2014.

3. Nihalani BR, Vasavada AR. Single-piece AcrySof intraocular lens implantation in children with congenital and developmental cataract. J Cataract Refract Surg. 2006;32(9):1527-1534.

4. Bellucci R. An Introduction to Intraocular Lenses: Material, Optics, Haptics, Design and Aberration. In: Güell JL, editor. Cataract. ESASO Course Series. Basel: Karger; 2013. p. 38-55.

5. Bazvand F, Mohebbi M, Bashiri S, et al. Outcome of single-piece intraocular lens sulcus implantation following posterior capsular rupture during phacoemulsification. J Ophthalmic Vis Res. 2017;12(3):275-280. 
6. Petternel V, Menapace R, Findl O, et al. Effect of optic edge design and haptic angulation on postoperative intraocular lens position change. J Cataract Refract Surg. 2004;30(1):52-57.

7. Vasavada AR, Raj SM, Karve S, Vasavada V, Vasavada V, Theoulakis P. Retrospective ultrasound biomicroscopic analysis of single-piece sulcus-fixated acrylic intraocular lenses. J Cataract Refract Surg. 2010;36(5):771-777. 